\title{
Differences between Students of two Different Study Programs in Assessment of Water Sports Teaching Standard
}

\author{
Bor Oreb, Nikola Prlenda and Goran Oreb \\ University of Zagreb, Faculty of Kinesiology, Zagreb, Croatia
}

\begin{abstract}
A B S T R A C T
The aim of the research was to determine if there was a difference in assessment of pedagogical-material standard in Water sports teaching between students of the Old study program in the period from year 2001 to year 2007 and students of the New (Bologna) study program in the period from year 2010 to 2015. The research was conducted on 2400 students, of which 1797 student entered the sample. Students have assessed 12 variables on a five-grade Lickert type scale through anonymous questionnaire. Variables of assessment were traveling, accommodation, food, teachers, assistants, vessels, climate and curricula for sailing, windsurfing, rowing and kayaking. The results of the arithmetic means for each variable were more positive for students in the new study program. Total arithmetic mean for the Old study program was 4.15 , and for the New study program it was 4.46. Based on the results acquired it is determined that there is a difference in assessment between the students of the Old study program and the students of the New study program.
\end{abstract}

Key words: students, sailing, windsurfing, rowing, kayaking, teaching

\section{Introduction}

Water sports is one of the regular subjects on the Faculty of Kinesiology of the University of Zagreb. Curriculum is realized through theoretical, theoretical-practical and practical teaching. The aim of the subject is to convey to students basic theoretical and practical knowledge on structure of movement, methods of teaching, learning and training and also application value of Rowing, Kayaking, Sailing and Windsurfing in the fields of education and recreation.

Due to small number of teaching hours (60 hours) teachers and assistants are trying to amend the evident deficiency of lessons for as much as four mentioned Olympic sports through organization of the subject. The subject has been held in its today's form since 1999, and great efforts are invested to increase the quality of realization of teaching. According to Old study program curriculum (until2009) the subject was held at the end of 8th semester, being the last subject students were taught in undergraduate study for those generations. According to New study program (since 2008) Water sports teaching is held in 6th semester of integrated graduate study. The teaching is held so that in the beginning of the summer semester theoretical lectures are held and in the same time theoretical-practical lessons are conducted in rowing, first in the rowing gym and after on a rowing track on the lake(Jarun-Zagreb). At the beginning of June students go to the field teaching which is held in the aquatorium of Badija, situated between Korčula island and little island of Badija. Through seven-day field lessons, students were acquiring knowledge in sailing, windsurfing and kayaking.

Organization of the field teaching consists of transportation to the site of training, accommodation, food, material-technical conditions and professional staff to carry out the teaching process. With the aim of increasing the quality of the teaching, from the year 2001 anonymous questionnaire was conducted among students. Based on its results it is attempted to increase the quality of organization of Water sports teaching. Monitoring of attitudes of students until today shows high satisfaction with the teaching realized (Oreb, Barešić, Oreb, Prlenda, \& Kostanić 2009). Using the questionnaires other authors too are discovering possible deficiencies, differences between groups in the teaching process, and on that basis they are willing to improve their own teaching (Cigrovski, Radman, Matković, Gurmmet, \& Podnar, 2014; Duplančić, Mladineo, \& Drašinac, 2008; A. Redžić \& M. Redžić, 2003).

The aim of the research is to determine possible differences between students of the Old study program in the period from the year 2001 to the year 2007, and the students of the New study program (Bologna program) in the period from the year 2010 to 2015 in the assessment of the pedagogical-material standard of the Water sports teaching.

\section{Methods}

\section{Subjects}

Population of the examinees in the period from the 2001 to 2015 consisted of 2400 regular male and female students of Kinesiology faculty of the University of Zagreb. 770 of those examinees were students of Old study program until year 2007, and 1027 of them were students of New (Bologna) study program from 2010 to 2015 . Because of the overlapping of the generations in 2008 and 2009, 603 examinees were not included into analysis, so the total number of examinees taken into analysis was 1797 , consisting of men and women in the age of 21 to 25 .

\section{Variables}

At the end of the teaching process, examinees filled out an anonymous questionnaire constructed with the aim of assessment of pedagogical-material standard of the practical teaching of Water sports. The questionnaire consisted of 12 variables 
which were graded by students using grades from 1 to 5 , where 1 meant very bad, 2-bad, 3-good, 4-very good, and 5-excellent. Variables consisted of questions for assessment of traveling arrangements, accommodation, food, teachers, assistants, vessels, curriculum, sailing, windsurfing, rowing, kayaking and climate.

\section{Procedures}

Water sports as a subject integrates curricula for sailing, windsurfing, rowing and kayaking. The field teaching lasts for total 8 days including traveling, of which there is 7 days of practical teaching, and on the last day there is also a practical exam. In one week, teaching is conducted for maximum $45 \mathrm{stu}-$ dents divided into 3 teaching groups of 15 students each. Basic programs in sailing, windsurfing, and rowing (kayak-canoe) are realized through 2 school lessons a day for every individual activity, on a principle of stations. In every teaching group demonstrators, teachers and the subject teacher are demonstrating and teaching basic elements of technique for the aforementioned sports.

Sailing lessons were conducted on ballast keel sailboats for four person. A teacher was present on every sailboat. Windsurfing was conducted under direct guidance of teachers and demonstrators. Ashore teaching was conducted using simulators, while on the sea multipurpose stabile boards were used with suitable sails. For rowing (kayak-canoe) stable tourist ,,siton-top" type kayaks were used. The lessons were carried out from 8:30 to 13:00 hours, and after students had arranged lunch in a hotel. Afternoon hours were reserved for training of acquired elements of the technique for individual sport. The test was conducted on the seventh day, after morning lessons were completed and after lunch break.

\section{Statistical analysis}

Using Excel 2013 program, arithmetical means were calculated for all the examinees by year and by every variable specifically. On the basis of acquired arithmetical means the difference in assessment between students of the New study program and the Old study program was determined, both in total and for every variable specifically.

\section{Results}

To determine the differences between examinees, students of the Old study program, and examinees, students of a New study program (Bologna program) results of the arithmetical means were compared for every answer (Table 1) and results of arithmetical means by single variable (Table 2).

Table 1. Arithmetic means for old and new study program

\begin{tabular}{cccc}
\hline $\begin{array}{c}\text { Study } \\
\text { program }\end{array}$ & Year & AM & $\begin{array}{c}\text { Total am for } \\
\text { period }\end{array}$ \\
\hline \multirow{4}{*}{ Old } & 2001 & 3.52 & \\
& 2002 & $/$ & \\
& 2003 & 4.08 & \\
& 2004 & 4.28 & 4.15 \\
& 2005 & 4.43 & \\
& 2006 & 4.38 & \\
(Bologne) & 2007 & 4.20 & \\
New & 2010 & 4.46 & \\
& 2011 & 4.36 & \\
& 2013 & 4.49 & 4.46 \\
& 2014 & 4.55 & \\
\hline
\end{tabular}

Note: AM-arithmetic mean

It is visible from the table that all the results are more positive for students in the new study program. The greatest change is visible in variables Kayak (1.34), Windsurfing (0.9), Sailing (0.87) and Traveling (0.84). The smallest change is present in variable Accommodation (0.11) and Climate (0.12). The highest grade by examinees of the old study program was assigned to variables Climate (4.62), Assistants (4.48) and Food (4.40), while the examinees of the new study program assigned the highest grades to the variables Sailing (4.79), Windsurfing (4.78), Food (4.78) and Climate (4.74). The lowest grades were assigned to the variables Kayak, Traveling and Rowing by all the examinees.

Table 2. Results of the arithmetical means of variables and their differences

\begin{tabular}{lllc}
\hline Variable & AM & AM & \multirow{2}{*}{ Difference } \\
\hline Traveling & Old & New & \\
Accommodation & 4.79 & 3.63 & 0.84 \\
Food & 4.40 & 4.15 & 0.11 \\
Teachers & 4.34 & 4.68 & 0.38 \\
Assistants & 4.48 & 4.69 & 0.34 \\
Vessels & 4.27 & 4.73 & 0.46 \\
Curriculum & 4.20 & 4.61 & 0.41 \\
Sailing & 3.92 & 4.79 & 0.87 \\
Windsurfing & 3.88 & 4.78 & 0.90 \\
Rowing & 3.22 & 4.05 & 0.83 \\
Kayak & 2.52 & 3.86 & 1.34 \\
Climate & 4.62 & 4.74 & 0.12 \\
\hline
\end{tabular}


The results in Table 1 show arithmetic means acquired on the basis of 12 variables for each generation in the period from 2001 to year 2015. Total average grades are in the scope from 3.52 to 4.55. Maximum grade was recorded in 2013 (4.55), and minimum in year 2001 (3.52). In the period from year 2001 to 2007 total arithmetic mean was 4.15 , and from 2010 to 2015 it was 4.46 .

\section{Discussion}

By inspecting the results in the Table 1 it is visible that total arithmetic mean for Old study program was 4.15 , and for the New study program 4.46. The difference of 0.31 is in favor of the New study program. The reason for such a result can be found in the increasing of the quality of teaching, and also in the more mature approach of the students of the New study program. More mature approach of the students of the New study program can be the result of positioning of the subject in the middle of the study, as opposed to the Old study program where Water sports were the last subject before the end of study. Based on those results, it is possible to conclude that positioning of individual subjects in the course of study affects the total assessment of quality of conducted lessons. Besides, it is important to mention that teaching process affects the attitude towards individual sport (Vlašić, Oreb, \& Katović, 2012; Cigrovski et al., 2014). Since in the aforementioned research questionnaire was conducted at the end of teaching process,

\section{R E F E R E N C E S}

Aranson, G., Wilson, T.D., \& Akart, R.M. (2005). Socijalna psihologija. Zagreb: Mate.

Cigrovski, V., Radman, I., Matković, B., Gurmmet, S., \& Podnar, H. (2014). Učinci programa alpskog skijanja nastave prema alpskom skijanju. Kineziologija, 46(1), 46-51.

Duplančić, D., Mladineo, M., \& Drašinac, G. (2008). Analiza stanja u prostoru zadovoljstva nastavom tjelesne i zdravstvene kulture. In: Neljak, B. (ed.). 17. Ljetna škola kineziologa Hrvatske, Poreč, 267-271.

Oreb, G., Barešić, M. Oreb, I., Prlenda, N. \& Kostanić, D. (2009). Stavovi i interesi studenata $i$ studentica kineziološkog fakulteta prema praktičnoj nastavu sportova na vodi. In M. Andrijašević (ed.). Upravljanje slobodnim vremenom sadržajima sporta i rekreacije. Zagreb: Kineziološki fakultet Sveučilišta u Zagrebu, 177-184.

Prlenda, N., Oreb, I., \& Cigrovski, V. (2011). Differences in effectiveness of teaching of sailing techniques using different great influence was surely made by the teaching staff too. The importance of choosing quality teaching staff is great, especially if we know that attitude is permanent evaluation of people, objects and ideas (Aranson, Wilson, \& Akart, 2005) and that once formed, such attitudes are very hard to change, as long as there is a functional and motivational basis on which the attitude is formed. When the results shown by variables are assessed (Table 2) it is evident that all the results are also in favor of the New study program. The greatest change is visible in the variables Kayak (1.34), Windsurfing (0.9), Sailing (0.87) and Traveling (0.84). It is assumed that the great increase in the variable Traveling is influenced by building the Zagreb-Ploče highway. Mentioned section of the highway opened in 2013, while shorter section to Vrgorac opened in 2010. Specified section greatly accelerated traveling on a relation Zagreb-Korčula, affecting certainly the satisfaction level in examinees. It can be assumed also that in variables Kayak, Windsurfing and Sailing by developing of methodic approach in teaching (Prlenda, Oreb, \& Cigrovski, 2011; Prlenda, 2012.) as by investing in the more modern equipment, learning of mentioned sports was facilitated. In the end it is expected that all those things combined affected the formation of a more positive attitude towards those sports. The least, but still visible increase was in assessment of the variable Accommodation (0.11) and Climate (0.12). Considering that those two variables have not changed, shows that improvement in individual factors resulted in increase of total satisfaction rate in examinees, although it was very high also in the students of the Old study program. methodic procedures. In: Proceeding book " $2^{\text {nd }}$ International scientific conference Exercise and quality of life", (69-72). Novi Sad: Faculty of sport and physical education, University of Novi Sad.

Prlenda, N., Oreb, G., \& Kostanić, D. (2010). Konstrukcija skale za procjenu stave prema jedrenju. Zbornik radova 19 . Ljetne škole kineziologa republike Hrvatske, (282-287). Zagreb, Hrvatski kineziološki savez.

Redžić, A., \& Redžić, M. (2003). Stavovi studenata Pomorskog fakulteta u Rijeci prema nastavu tjelesne i zdravstvene kulture. U V. Findak (ed.) Zbornik radova 12. Ljetne škole kineziologa Republike Hrvatske, (268-271). Zagreb: Hrvatski savez pedagoga fizičke kulture.

Vlašić, J., Oreb, G. \& Katović, D. (2012). Dance attitude difference between female and male students. Ovidius University annals series physical education and sport, 12(suppl.2), 417-421.

\author{
N. Prlenda \\ University of Zagreb, Faculty of Kinesiology, Horvaćanski zavoj 15, 10000 Zagreb, Croatia \\ e-mail:nikola.prlenda@kif.hr
}


